\title{
Development of GIS for Buildings in the Customary Village of Minangkabau Koto Gadang, West Sumatra, Indonesia
}

\author{
Surya Afnarius ${ }^{1, *(\mathbb{D}}$, Masril Syukur ${ }^{2}$, Eri Gas Ekaputra ${ }^{3}$, Yolanda Parawita ${ }^{1}$ and \\ Ridho Darman ${ }^{1}$ (D) \\ 1 Department of Information System, Andalas University, Padang 25166, Indonesia; \\ 1511521013@student.unand.ac.id (Y.P.); 1511522004@student.unand.ac.id (R.D.) \\ 2 Department of Civil Engineering, Andalas University, Padang 25166, Indonesia; masril@ft.unand.ac.id \\ 3 Department of Agriculture Technology, Andalas University, Padang 25166, Indonesia; erigas@ae.unand.ac.id \\ * Correspondence: surya@it.unand.ac.id
}

Received: 30 April 2020; Accepted: 29 May 2020; Published: 2 June 2020

check for updates

\begin{abstract}
Indonesia aims to strengthen its local regions and villages. This has led to the encouragement of smart village development through several forms of assistance, including Information Technology (IT) services from the government. Koto Gadang, one of the many Minangkabau customary villages in West Sumatra, has been used as a model for the development of an IT service that can support tourism known as a Web- and mobile-based geographic information system (GIS) for buildings (GB) in order to map and visualize buildings and their inhabitants. This paper reports the development of the GB. This study takes the form of a literature review, a survey, data collection, and software development. The results of the literature review and survey were used as the basis for software development. Aerial photographs of micro, small, and medium enterprises (MSMEs), mosques, offices, schools, and health service centers, as well as residential buildings, were taken using a drone, while attribute data were collected directly by visiting the buildings. The users of the GB were divided into two groups: visitors and village officers. Moreover, there confidentiality was maintained for all the data provided, so the visitors were only allowed to search for buildings (MSMEs, offices, mosques, schools, and health centers) based on certain criteria, view locations, found information, and survey routes, while village officers were allowed to collect data on residents, buildings, and houses, and also search people's homes. Furthermore, in situations where a visitor needs to find a resident's house, the village officers are required to provide this assistance. These provisions were applied in the GB and implemented using the PostgreSQL/PostGIS database, PHP, CSS Bootstrap, jQuery, and Basic4Android, created according to the needs of the Koto Gadang smart customary village. The GB allows the village officers to better understand and monitor all the buildings, houses, and residents in the village and could also encourage many travelers to visit and see historic buildings and shop for embroidery and silver crafts.
\end{abstract}

Keywords: a web- and mobile-based GIS; buildings; drone; IT service; map and visualize; residents; smart customary village

\section{Introduction}

Indonesia has a total population of 270.6 million, of which 120 million people live in 74,093 villages [1]. Development and industrial growth are a problem in Indonesia in general, but specifically in these villages. However, there is large potential for tourism in this area. Therefore, a national strategy named Nawacita was developed. The third point of Nawacita is to build Indonesia by strengthening local regions and villages within the framework of the unitary state [1], with rural development as the top priority. The development of these villages is important due to the fact that the 
rates of poverty and underdevelopment here are much higher than those in cities [2]. This agenda is in line with the Village Law Number 6 of 2014 [2-4], with an emphasis on providing the villages with $10 \%$ of the development budget and state expenditure of Indonesian Rupiah (IDR) 20.77 trillion [1]. The law also emphasizes the need for transparency and accountability in the use of such funds [3]. Therefore, the government is responsible for providing and fulfilling IT services in order to encourage the creation of smart villages.

The authors in [5] discussed smart technology in the context of a smart village. According to [5], "smart means using digital technologies when they are appropriate". A smart village is a rural area "enhanced by means of digital communications technologies, innovations, and the better use of knowledge for the benefit of the inhabitants" [5]. Moreover, a smart village is defined as "a concept which refers to a set, series, or even a bundle of services being delivered to a group of residents inhabiting a certain rural area" [6]. It is also explained as "a village that is able to identify, know, and provide various needs and services for the community in order to improve the quality of life" [7]. A smart village is characterized by the use of IT. However, despite these descriptions, there is no universally accepted definition for the concept of a smart village. Likewise, the development of smart villages is still new and not as advanced as that of smart cities.

Several countries in the world are actively developing smart villages, including several in Europe and Asia, such as Malaysia and Thailand, which have taken the initiative to implement smart villages by using IT services, as observed in the Phu Kradueng National Park, the e-Bario project, and Long Lamai [8-10]. The utilization of these IT services via internet technology has the ability to improve the welfare of rural communities by supporting and opening market access for the handicraft industry and homestay tourism. The authors in [11] further stated, "there is an urgent need to design and develop smart villages to ensure the independent provider of services". This development is, however, expected to be based on local geographic conditions and the availability of infrastructure [11,12]. The solution must be based on local knowledge and local needs [5]. The next question to ask is "what kind of IT should be built and developed in smart villages?' Moreover, according to [11], “Geo-informatics technologies can play a very prominent role in the deployment and implementation of ICT in the smart village" and "GPS, remote sensing, web-services, and location-based services and technologies can support innovative solutions". This is also in line with the opinions in [12-14]. This, therefore, means that the essential components for building smart villages include geospatial data and GIS. Even in Indonesia, the GIS is used as an indicator of a successful smart village program [15]. However, its application at the village level is still a challenge due to the lack of spatial information in rural areas, weak infrastructure, and the high costs of implementation [16-18].

Some researchers have discussed several problems related to buildings and residents with respect to the development of smart villages. The authors in [16] reported that "a centralized information system on land administration services, houses, and its occupants is an important aspect for Padang Lua and other villages in Minangkabau". The authors in [17] also asserted there is a home for all, while [19] suggested that the purpose for smart villages is to ensure homes with access to a toilet and that "a smart village knows all information about its citizens and available resources". This researcher also reiterated the need for the collection of building data in creating these villages, and the same was also observed in [20]. The development of the GIS for rural villages starts with the creation of a spatial database of buildings, houses, and residents. The authors in [21] reported that the "GIS analysis ensures all the houses in rural areas are well connected through rural roads." These findings illustrate the importance of developing a GIS for buildings and inhabitants as the first step towards the successful implementation of smart villages. However, the GIS developed for buildings and inhabitants does not yet support tourism.

The importance of data collection in developing smart villages has led the village government of Koto Gadang to manually obtain information on buildings and residents through the use of a survey team, after which the data obtained were stored on a computer using Microsoft Excel. This method is not effective since it is very vulnerable to duplication or data input errors, and the information saved is 
only obtainable at the village office during office hours [22]. Moreover, the data have not yet been visualized in digital village maps or utilized in Geo-informatics technology to develop IT services; others have used Google Earth to build digital maps [21,23-25]. Some villages in Indonesia have even used drones to take aerial photographs of villages in an effort to develop digital village maps [26-28].

Therefore, to overcome the problem of building and resident information services in Koto Gadang to help the area become a smart customary village, an IT service that can support tourism known as Web- and Mobile-based GB was built to map and visualize the buildings and inhabitants through funding provided by the state. This paper reports the development of technological innovation and its ability to remedy the lack of spatial information in rural areas, weak infrastructure, and high costs and also provide answers to the needs of the smart village (i.e., information about the population and available resources). The simple availability and accessibility (anytime and anywhere) of the GB is in line with the study in [29-31].

\section{Materials and Methods}

\subsection{Study Area}

This research was conducted in the customary village of Minangkabau Koto Gadang in the Agam Regency, West Sumatra Province, Indonesia. According to [16], Minangkabau is "a cultural and geographical entity embracing the matrilineal kinship system with the descendant line taken from the women's side of a family". Koto Gadang is located on a hilly plateau and is partially restricted by the Sianok Canyon, which is West Sumatra's leading tourist destination. The village consists of three Jorong-Koto Gadang, Sutijo, and Gantiang. Koto Gadang is located between the Hill of Kapanehan, Mount Singgalang, and Mount Merapi with an altitude reaching 920-950 m above sea level. The average temperature in this village is around $20^{\circ} \mathrm{C}$, while at night, it reaches $10^{\circ} \mathrm{C}$ [32]. This is a strategic area directly adjacent to the Bukittinggi Tourism City and has a population of 2697 people, as well as 878 houses, 79 MSMEs, nine mosques, five offices, three schools, and two health service centers. The village has electricity and internet facilities, as well as the potential for land-use change and economic growth in the future [33].

Most of the villagers have migrated out of the village, which has led to several houses becoming unoccupied $[34,35]$. Most of the buildings employ Dutch architecture with high-value ornaments and beautiful Rumah Gadang Minangkabau. Even though the village looks deserted, this area features woven cloth and silver craftsmen. Indeed, for many decades, tourists visiting Bukittinggi often stopped by Koto Gadang to buy community handicrafts. This village is also famous for its special cuisine, Lado Itiak Hijau, which likewise attracts the attention of tourists [36], in addition to the presence of the tourism object, Janjang 1000. The location of the Koto Gadang customary village is shown in Figure 1.

\subsection{Steps for Conducting Research}

This research was conducted via a literature review, a survey, data collection, and software development. The first step was to conduct a review of several studies on the concept of smart villages, as well as the information technology required for their development. This was followed by a survey conducted in the form of interviews to understand the needs of the community, followed by system analysis, and collection of the required data. These activities aim to determine user needs and prepare to build a database. The interview material focused on developing an IT-based smart village. Interviews were conducted with the village head and secretaries, three guardians of Jorong, three village staff, and ten community leaders representing their tribes. The third step was to design the system, and the last step involved coding and testing the system. The key steps in the workflow are presented in Figure 2. 


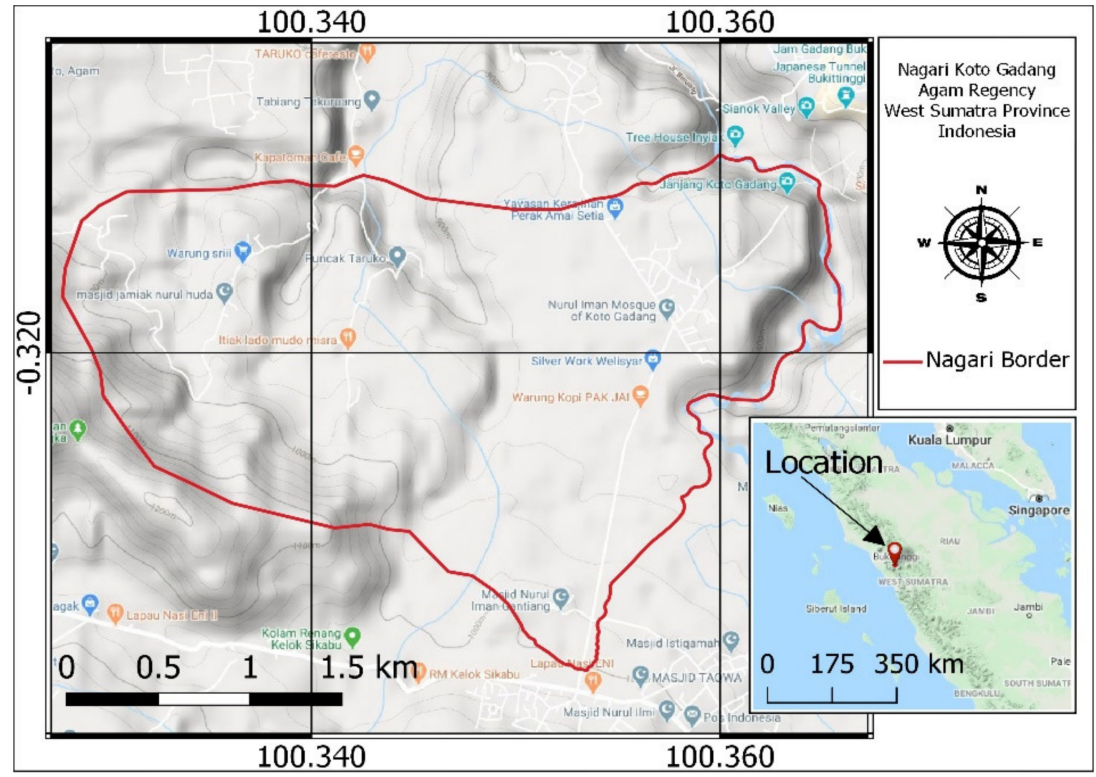

Figure 1. Map of the Koto Gadang customary village.

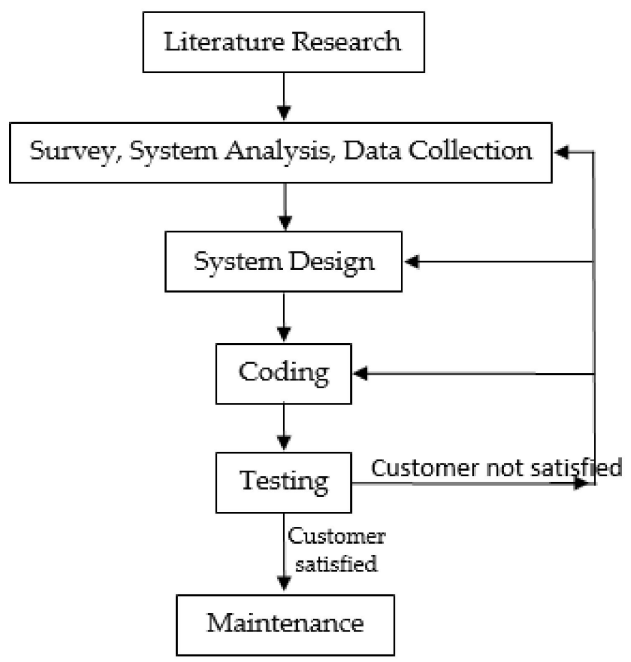

Figure 2. Flow chart of methods applied in this research.

The results of the literature review showed that the building of smart villages requires the use of IT as a dominant technology, especially through the application of Internet and Geo-informatics technology. Some additional technologies, such as Global Positioning System (GPS), remote sensing, web services, and location-based services, are also needed. However, the most important components include Geospatial data and GIS because the analysis and design of IT services for smart villages need to be based on local geographic conditions.

The interviews conducted in the community and village government revealed the following needs for Koto Gadang:

1. The need to apply IT services to buildings and residences to help the community search for a particular building, its information, and directions to its location.

2. The tourism potential of the village needs to be reawakened. In the past, tourists visiting Bukittinggi often visited Koto Gadang to see the Dutch heritage buildings, eat typical Koto Gadang duck curry dishes, and buy souvenirs of embroidery and silver handicrafts. In addition, there is already a new tourist destination, Janjang 1000, located in the Sianok Canyon, connecting Bukittinggi to Koto Gadang village. 
3. The confidentiality of population data, especially for residential buildings.

As previously stated, the users of the Web- and Mobile-based GB were divided into two groups-visitors and village officers. The confidentiality of the population data, including the location of residents' homes, was maintained by restricting visitors' access. This was made possible by ensuring the visitors were only allowed to (a) search for the location and building information based on certain criteria, such as displaying all MSME buildings and performing MSME building searches by name, MSME type, construction type, radius, Jorong and facility, and (b) see the route to the selected building. Meanwhile, the village officers have the ability to collect data on residents, houses, and buildings, as well as search for locations and information about homes based on population data. Accessing functions that can only be carried out by the village officers requires a username and password, whereas other functions do not require these credentials. The use case diagrams for the two groups of users are presented in Figures 3 and 4.

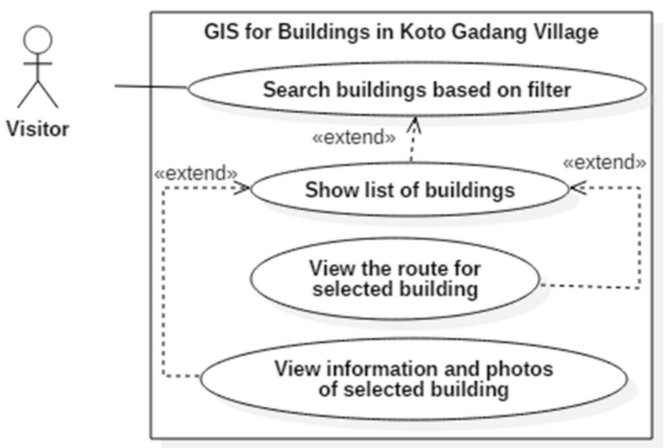

Figure 3. The use case diagram for visitors.

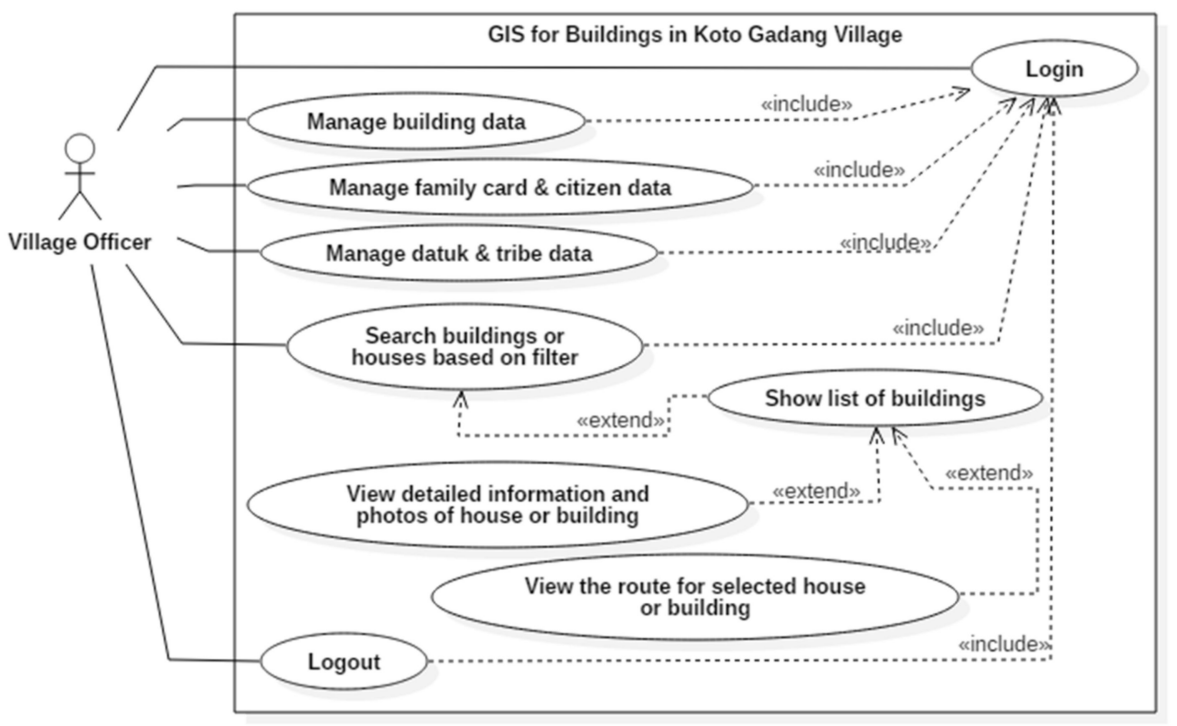

Figure 4. The use case diagram for village officers.

Several data were collected to build the database. For example, building attribute data were collected directly by visiting existing buildings with the assistance of 30 students from the department of civil engineering and information systems of Andalas University. Meanwhile, spatial data for the buildings were collected using high-resolution village aerial photographs, Unmanned Aerial Vehicles (UAVs), or drones-in this case, DJI Phantom 4. According to [26], a 1:1000 scale village mapping using drones is very appropriate, as this method can produce accurate maps with high accuracy of less than $0.20 \mathrm{~m}$. Detailed information is shown in [37]. The images produced were combined using 
Agisoft Photoscan and registered using ten ground control points, after which a digitization process was conducted to build the maps. The spatial data produced from digitizing the images in polygon data types were then imported into the PostgreSQL/PostGIS database.

The total number of aerial photographs taken with the drone was 1495. Figure 5 shows an orthophoto of the study area. The data collected during the field surveys were attached to the corresponding buildings digitized from the drone images based on the unique ID numbers (markers) assigned to each building. These numbers are shown in Figure 6, while those digitally completed are presented in Figure 7.

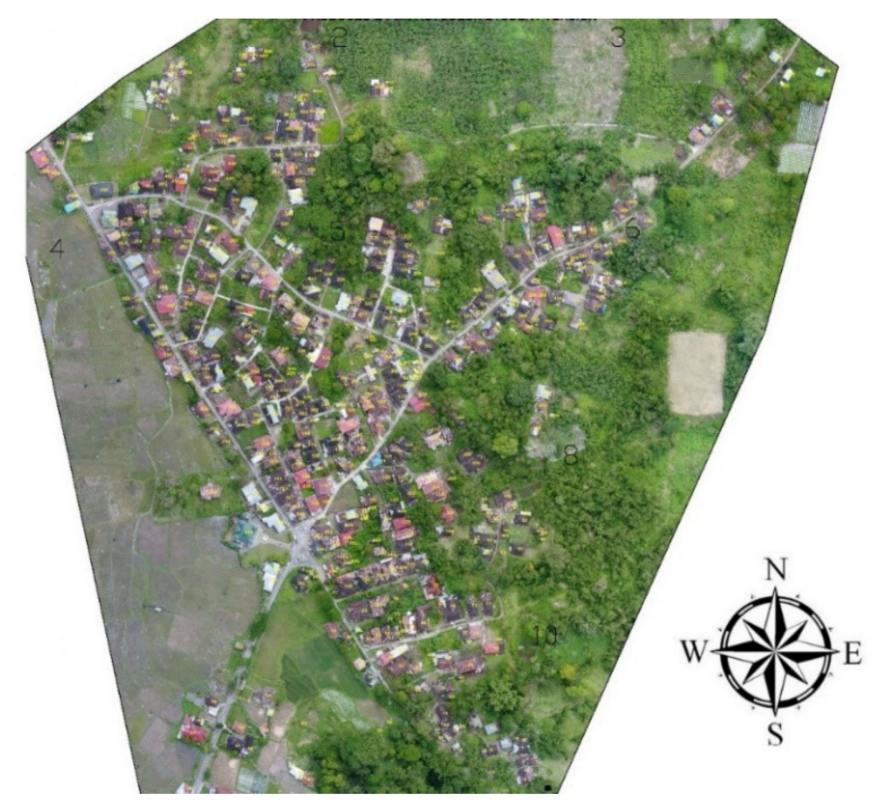

Figure 5. The orthophoto of the study area.

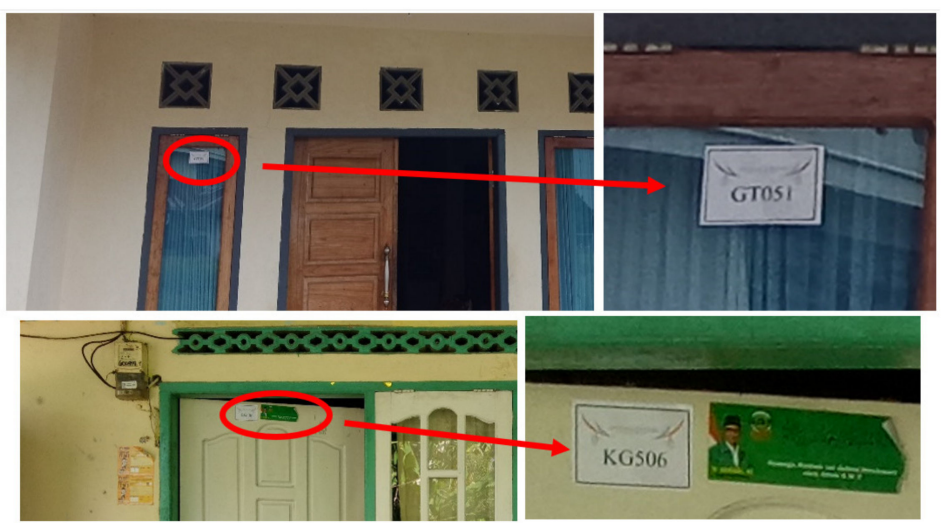

Figure 6. Markers of buildings where attribute data were collected.

The system analysis stage was followed by the design phase, which involved designing the user interfaces, databases, and processes of the GB. The web interface was designed using the Balsamiq Mockup application, while the mobile interface was designed using Basic4Android. Moreover, the database was designed according to the needs of the Koto Gadang villagers, as described in the use case diagram, and the output was an entity-relationship diagram (ERD). The interactions of the user with the GB through several processes are shown in Table 1. Figure 8 shows the system architecture diagram of the GB. 


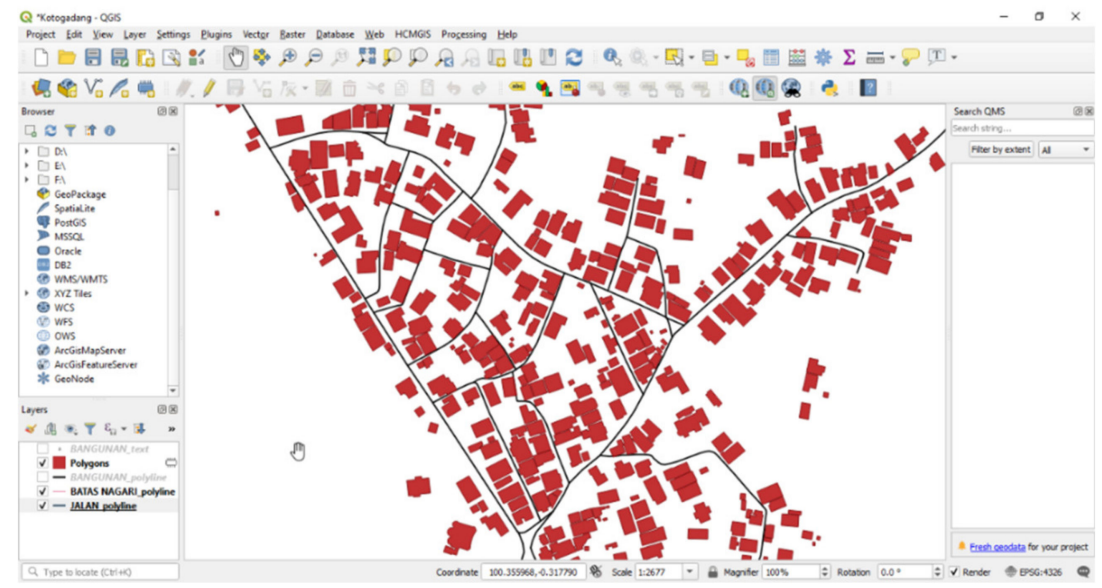

Figure 7. Building data digitalization.

Table 1. Displaying general information about the micro, small, and medium enterprise (MSME) building scenario.

\begin{tabular}{|c|c|}
\hline Use Case & Display General Information of MSME Building \\
\hline Participating Actor & User \\
\hline Entry Condition & The user receives the MSME building list \\
\hline \multirow[b]{3}{*}{ Flow of Events } & The user selects one of the existing MSME building lists or markers. \\
\hline & 2. The user presses the "view details" button. \\
\hline & $\begin{array}{l}\text { 3. The system displays pop-ups of general information about the selected } \\
\text { MSME building. }\end{array}$ \\
\hline
\end{tabular}

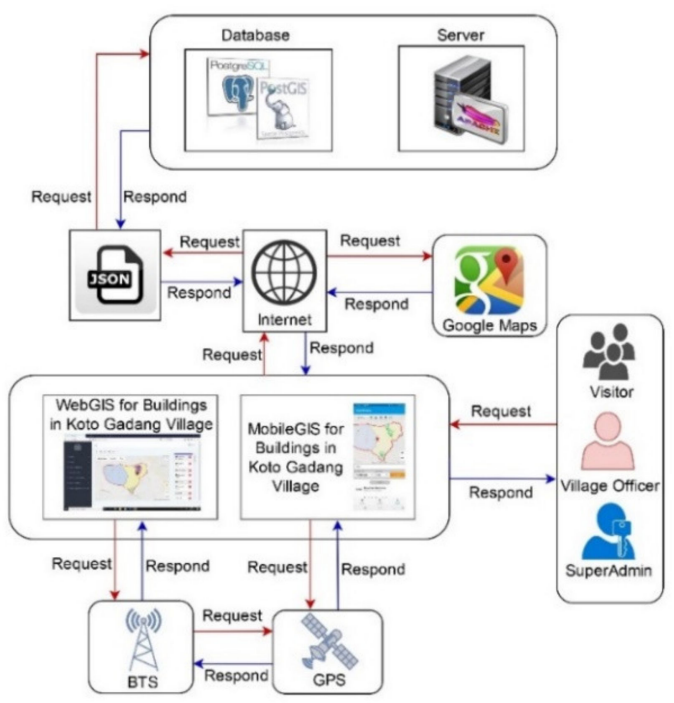

Figure 8. The system architecture diagram of the GIS for buildings (GB).

The data required by the GB include spatial data of the buildings, Jorong, and Nagari/village boundaries, while those pertaining to the attributes include data on the residents, family cards, tribes, and the datuk/tribal chief. Additionally, the spatial data include different types of buildings, such as offices, health services centers, schools, places of worship, MSMEs, and homes. For MSMEs, there are several types, including silverwork, embroidery, shops, restaurants, and various handicrafts. Figure 9 shows the entity relationship diagram of the GB. 


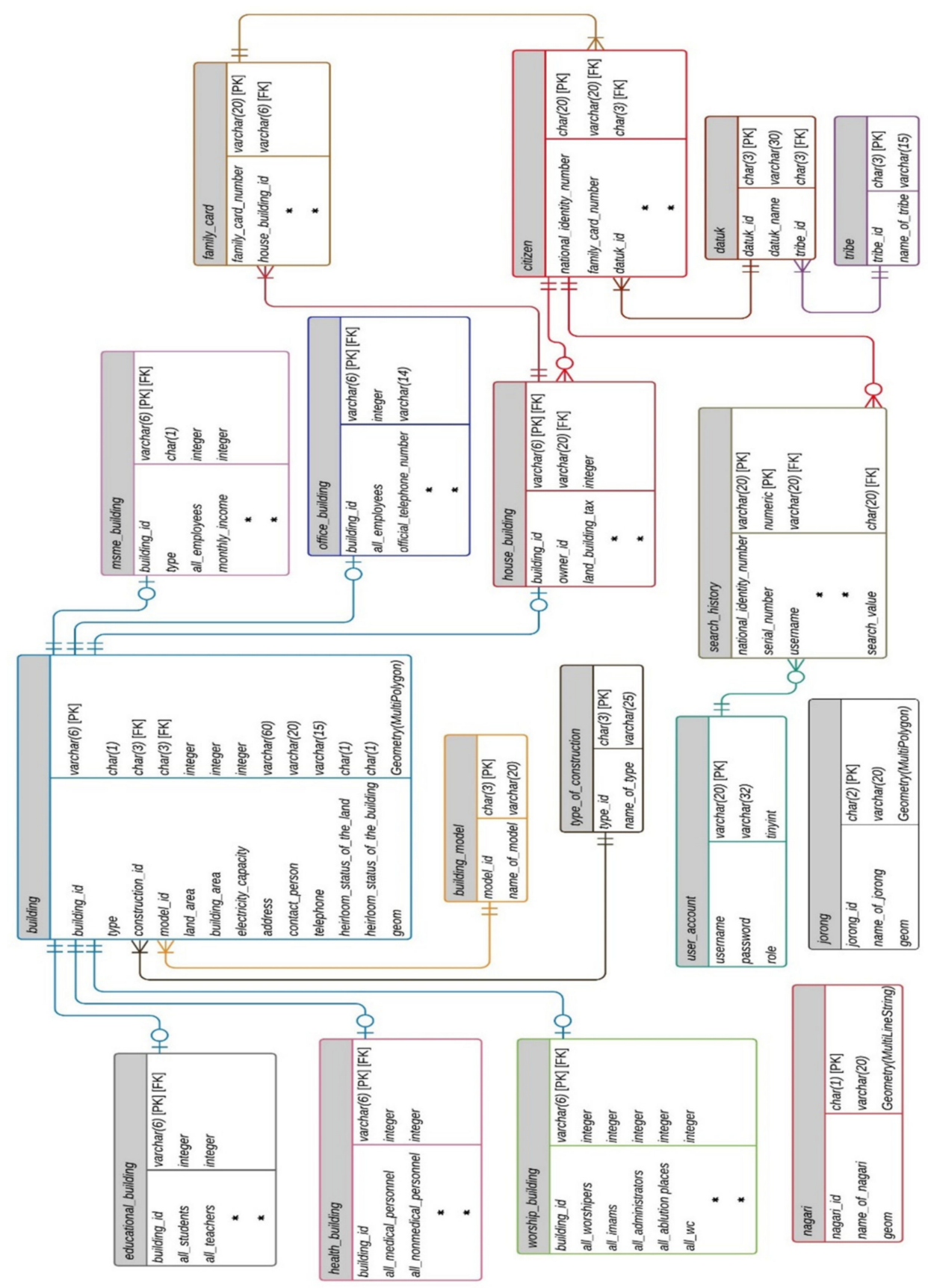

Figure 9. The ERD of the GB.

The database created consists of six main tables without any special relations. The tables were formed based on the use of buildings (namely, the MSME_building, office_building, worship_building, educational_building, health_building, and house_building tables). The relation of the building table with the six main tables is One to (Zero or One), where the primary key of the building table is the primary key and the foreign key in every six main tables. The building_model table is useful for supporting tourism of the Koto Gadang village. Meanwhile, in terms of spatial relations, all six main tables had coincidental relations. In addition to the six main tables, to link the house with their inhabitants, two other tables were developed, the family_card and citizen tables. The developed relationships are as follows: (1) the relation between the house table and the family_card table is One to (One or Many), where house: family_card_id becomes the foreign key in the family_card table, and (2) the relation of the family_card table with the citizen table is One to (One or Many), where family_card: 
family_card_number becomes a foreign key in the citizen table. Furthermore, so this GB can meet population needs according to Minangkabau customs, two other tables were created: the tribe and datuk tables. The tribe table relates to the datuk table in the form of One to (One or Many). The datuk table is related to the citizen table in the form of One to (One or Many).

The last step was to code and test the system. This involved implementation of the ERD design in the PostgreSQL/PostGIS database, with PostGIS used to spatially enable PostgreSQL [38-40] due to its ability to perform better than MongoDB for neighboring select object operations and spatio-temporal data queries [41-43]. Both the spatial and attribute building data were imported into the database, and the processes made for the GB were implemented using PHP, CSS Bootstrap, jQuery, and Basic4Android. Moreover, the Google Maps application was used to display maps of the Koto Gadang village buildings. The GB was later tested for functionality and usability to ensure that the products would behave according to the user's needs and be able to complete their intended tasks.

\section{Results}

The GB was developed using PHP, CSS Bootstrap, jQuery, and Basic4Android, while the attribute and spatial data were stored in a PostgreSQL/PostGIS database, and Google Maps was used as the base map. To display the route to a building, the Google Maps API Directions Service function was used. After the completion of the GB, the system was tested in different places, such as the office of the village head, mosques, hospitals, restaurants, and houses. Overall, the results were satisfactory, with the following pictures showing that the needs of the visitors were met by the developed GB. Moreover, Figure 10 shows the MSME buildings located within $100 \mathrm{~m}$ of the location of a tester standing in Tapi Nurul Iman mosque, while the route to the searched building-Denny Silver Work-is shown from the tester's position, as presented in Figure 11. The tester can also look for mosques with Dutch buildings. Figure 12 shows a mosque with a Dutch building.
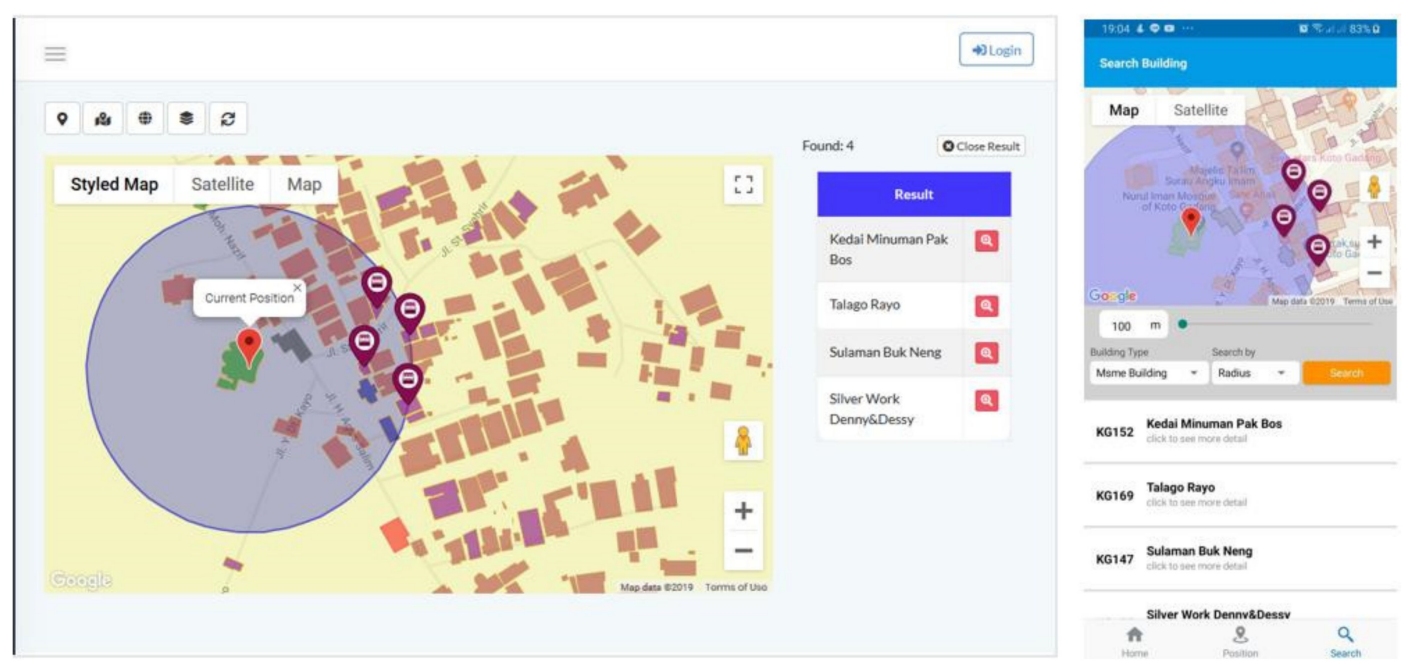

Figure 10. MSME building search around the tester's location.

The suitability of the GB for the needs of the village officers was tested, and the following pictures show that it is suitable. For example, Figure 13 shows the results of the search for a resident's house using an identification (ID) number of 1306051234560002 (dummy data). Figure 14 shows the search results based on the owner's tribe in Sikumbang. In addition to the use of an ID number and the tribe to search for buildings, the village officers were authorized to collect data on residents, residential buildings, and other existing buildings, as well as add to or update the master data for the buildings, including the MSME buildings. 

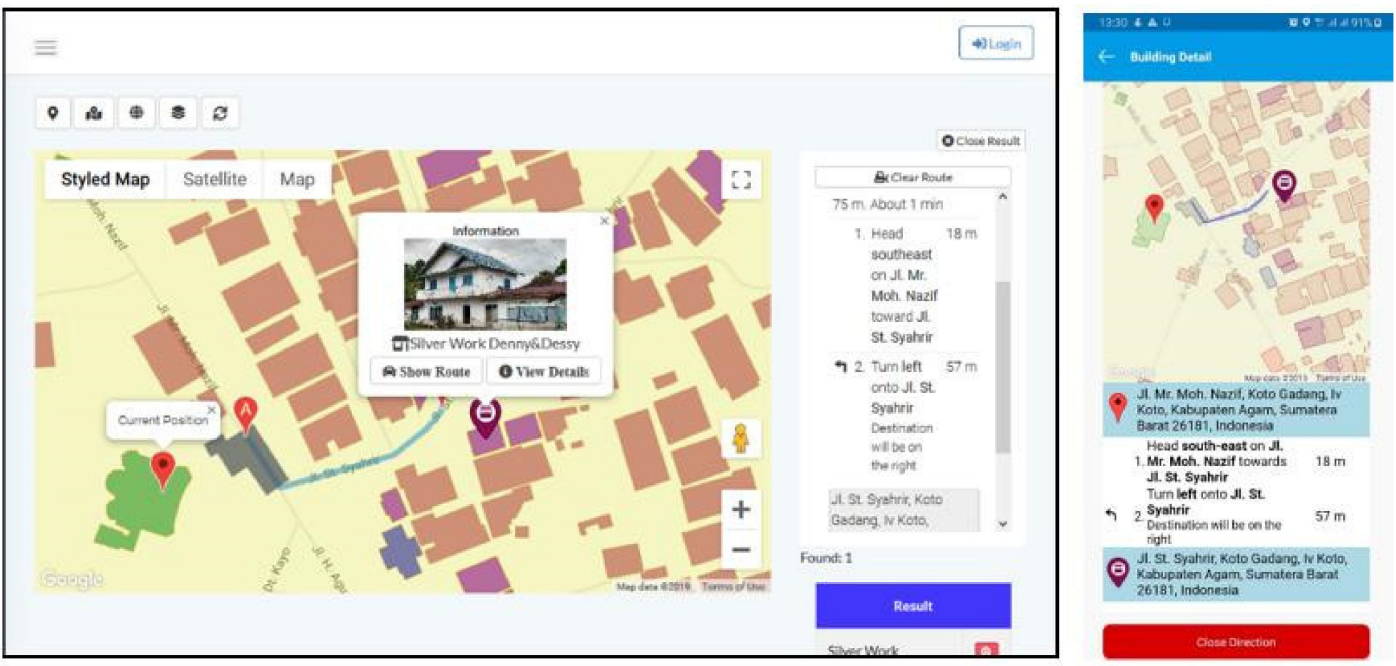

Figure 11. The route to the searched MSME building—Denny and Dessy Silver Work.
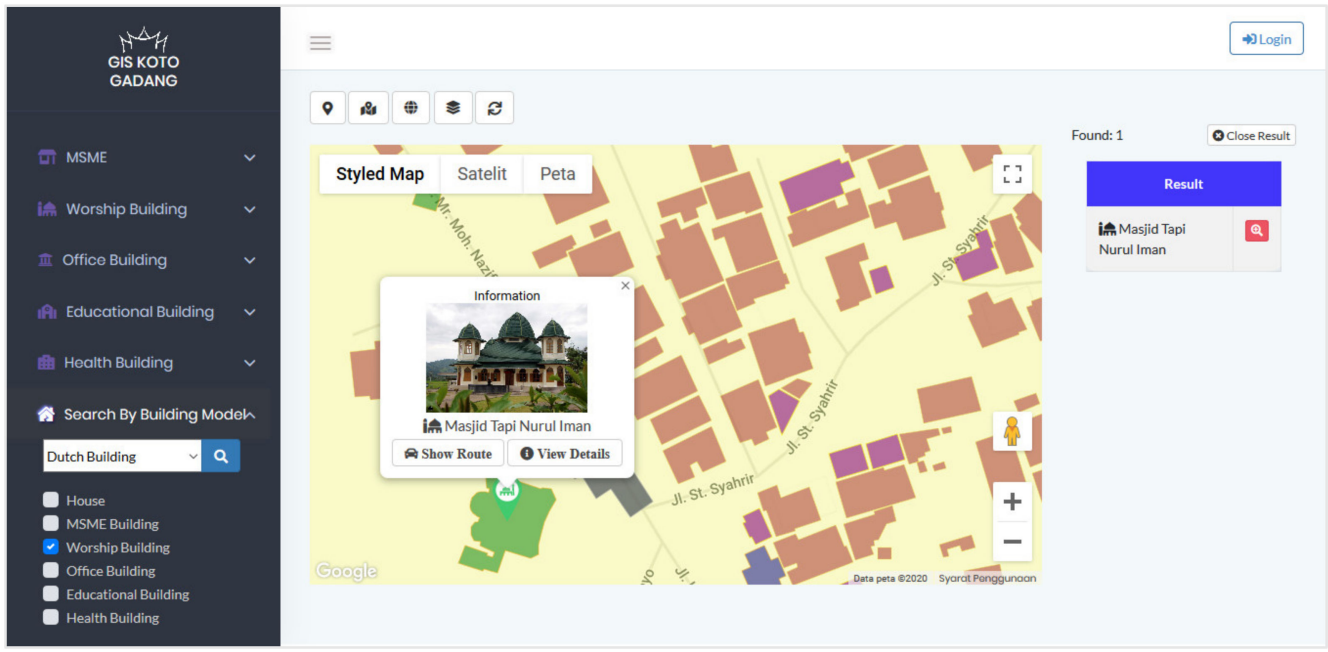

Figure 12. The mosque featuring Dutch architecture.

In addition to the functionality to be used by the village administration (Figures 13 and 14), village officers are also tasked with the responsibilities of helping visitors search for residents' houses based on ID numbers for residents of both Koto Gadang village and other outside communities. The ID number of the resident needs to be provided by the visitor. This is intended to ensure that the visitor has a relationship with the resident. However, visitors have to show their ID and mobile phone number for security reasons when they access certain residential locations. These data are stored as evidence that the visitor used a search service. Figure 15 shows a search service used to find a resident's house. For the purposes of this function, two tables are created: search_history and user_account tables. The search_history table is used to store search history data, while the user_account table, consisting of username and password fields, is used to store the data of the village officers who can access the villagers' home search function. 


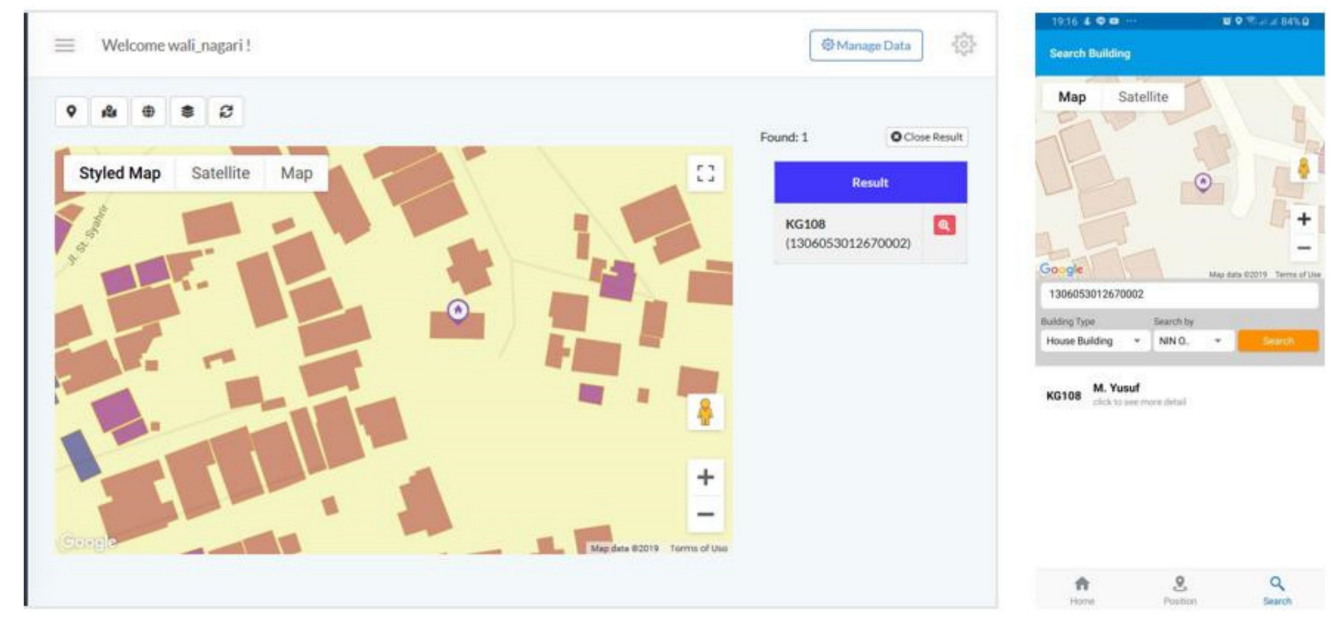

Figure 13. The results of the search for a resident's house using the ID number 1306051234560002.
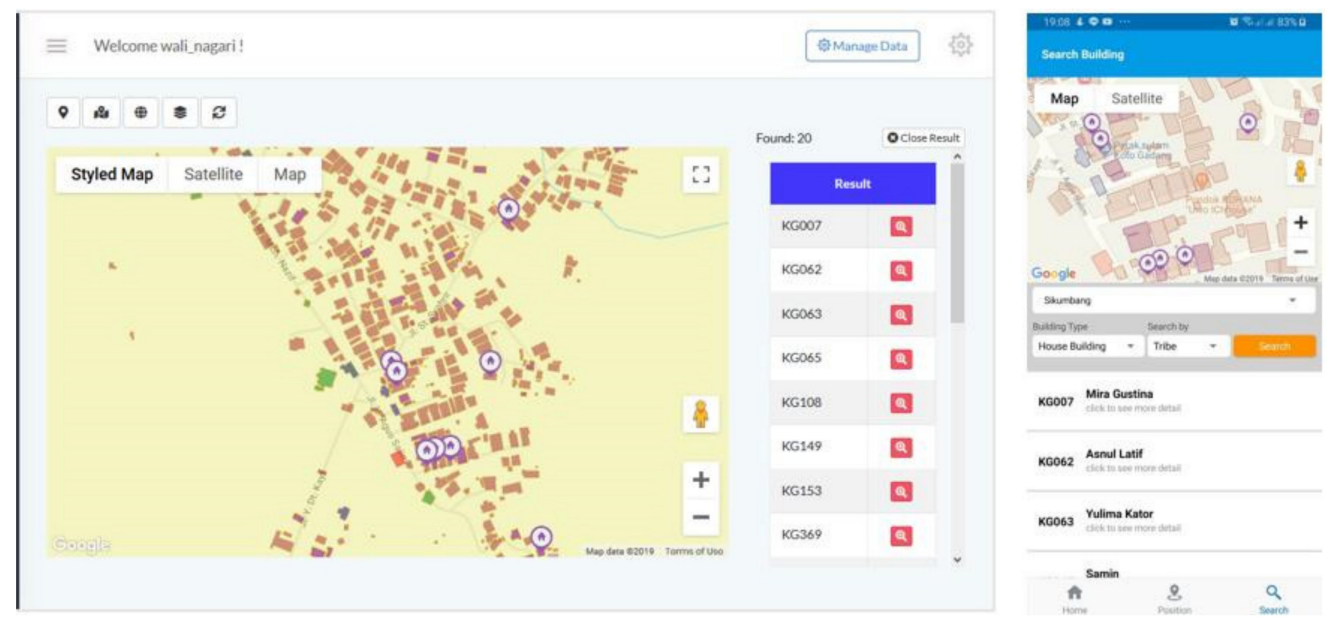

Figure 14. The search results for residents' houses based on the owners' tribes in Sikumbang.
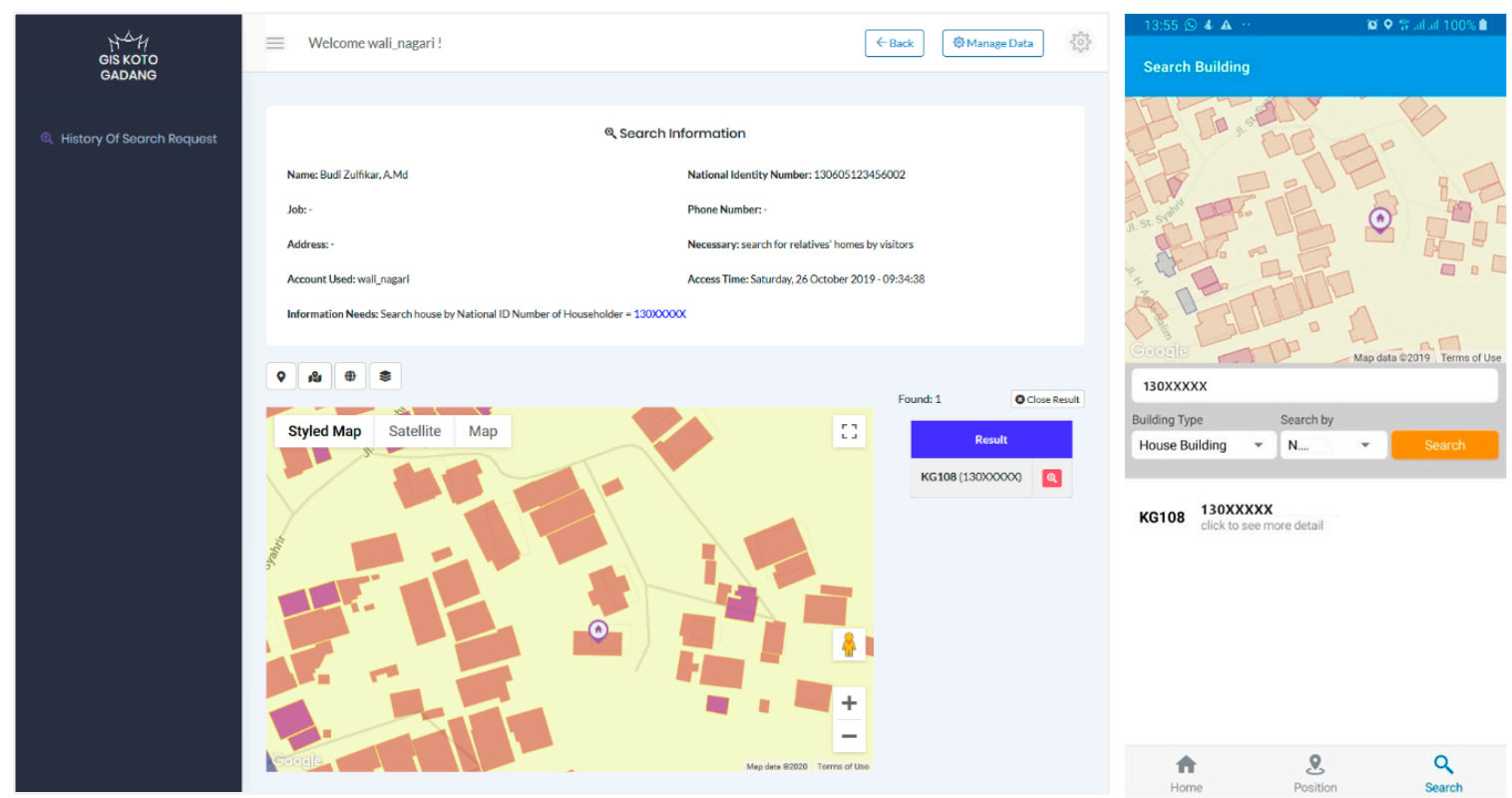

Figure 15. The search service used to find a resident's house. 


\section{Discussion}

The GB was created to improve the quality of life of rural communities. The GB also acts as a cyber-based system with an information infrastructure for village governance and economic activities. GB functions that support smart village activities include searching for (1) buildings (MSMEs, offices, mosques, schools, health centers, and houses), including information and routes to the location of the buildings, and (2) tourist attractions in the form of historical Dutch buildings and other tourism supporting industries, such as restaurants, embroidery, and silver handicraft MSMEs. This GB is an expansion of the GB developed in $[16,20,21]$. The authors in [20] analyzed the data needed for developing villages, including settlements, drinking water, health centers, and roads. The authors in [21] created a spatial database of buildings and their inhabitants. The authors in [16] established a land, building, and occupant information system that is in accordance with Minangkabau's customary rules regarding land and building ownership. Expansion is being carried out for the GB in the form of the creation of new functions for building management based on the use of the building, while, at the same time, supporting the tourism of Koto Gadang village. The applications of the buildings include the use of buildings for MSMEs, offices, mosques, schools, health centers, and houses. This GB has demonstrated its ability to assist the village officers in carrying out several village government services and supporting the village tourism industry.

Using the data collected and stored in the database, various conditions in the Koto Gadang village community in terms of electricity usage, clean water, income, and the condition of people's homes can be accessed by the village head. These data can be used for various purposes, such as village development planning, information on the average distance between houses, and a variety of needed public facilities. GB can produce graphs of the required information, as illustrated in Figure 16. From Figure 16, it can be seen that the average distance from a resident's house to a healthcare facility is $2104 \mathrm{~m}$, which is quite far. This distance calculation uses the PostGIS spatial function command, ST_Distance. ST_Distance calculates the distance of a straight line between two coordinate points. In addition, existing data can also be used to channel aid to communities affected by the COVID-19 outbreak. The government has decided to exempt electricity charges for people whose homes use 450 VA of electricity and give a $50 \%$ discount on electricity fees for those who use 900 VA of electricity. The GB that was created can display a map of the distribution of people's homes based on the use of electricity, as shown in Figure 17. Data on the electricity usage of each house is stored in the building table. These data are grouped based on electricity usage (i.e., $450 \mathrm{VA}, 900 \mathrm{VA}$, etc.).

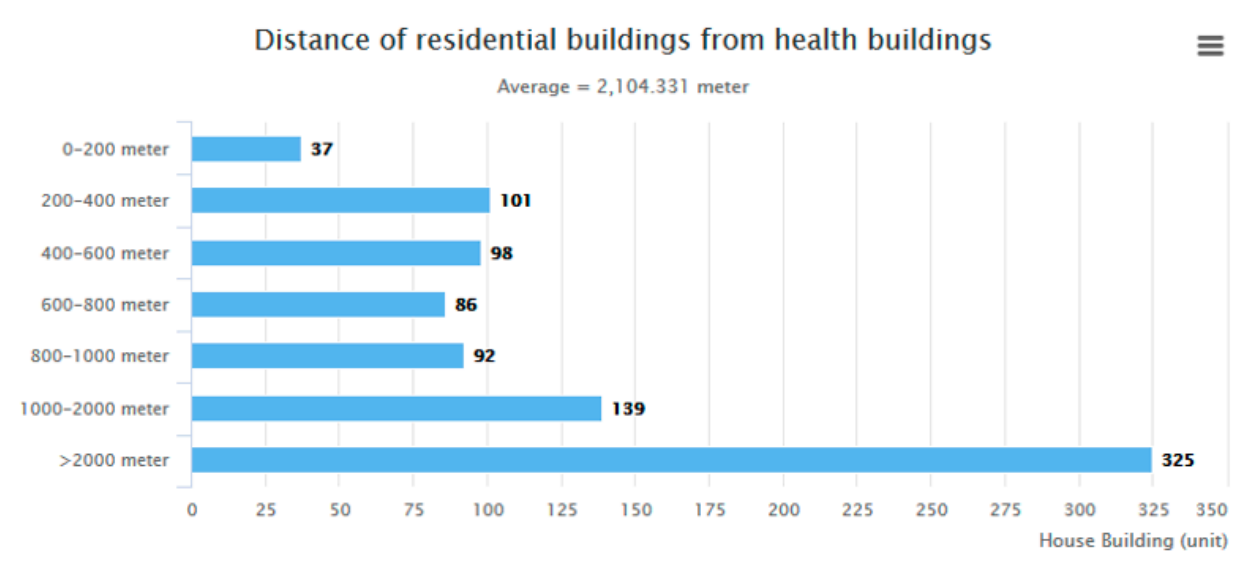

Figure 16. The average distance of residential buildings from health buildings. 


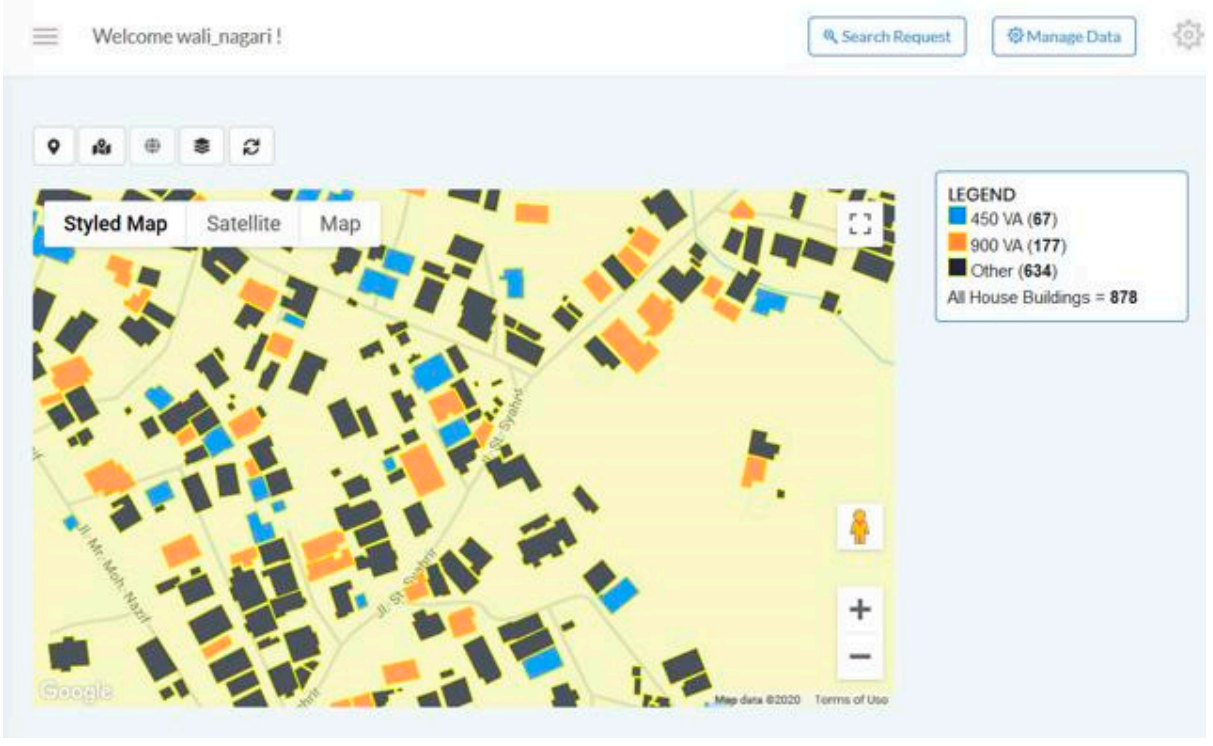

Figure 17. Map of the distribution of people's homes based on the use of electricity.

\section{Conclusions}

A Web- and Mobile-based GB was successfully developed for buildings in the customary village of Minangkabau Koto Gadang. This study was conducted through the use of a literature search, a survey, data collection, and software development. The data collected include spatial data for buildings, Jorong, and Nagari boundaries obtained from a drone, while those related to the attributes include data on residents, families, tribes, and datuk collected manually in the field. Based on the results of the literature review and survey, a database design, user interface, and process were developed. The expansion process was carried out by creating new functions to perform building management based on building use and, at the same time, support tourism of the Koto Gadang village. Furthermore, a GB was built using the PostgreSQL/PostGIS database and programmed using PHP, CSS Bootstrap, jQuery, and Basic4Android. The data collected were imported into the database, and then GB testing was performed. The results of the tests show that all the functionalities, both for the visitors and the village officers, run as expected and satisfied the users. The implications of this research will have a positive impact on government activities and tourism in the customary village of Koto Gadang. The results of this research will allow the village officers to better understand and monitor all the buildings, houses, and residents in the village and will also compel many travelers to visit and see historic buildings and shop for embroidery and silver crafts. These results could also be implemented in other customary villages in Indonesia and in other countries. The next study suggested is to examine the influence of GB developed on the activities of MSMEs (embroidery and silver crafts), tourism, and village government services.

Author Contributions: Conceptualization, Surya Afnarius; Funding acquisition, Surya Afnarius, Masril Syukur and Eri Gas Ekaputra; Software development and testing, Surya Afnarius, Ridho Darman and Yolanda Parawita; Data, Masril Syukur and Ridho Darman; Writing —original draft, Surya Afnarius; Writing_review and editing, Surya Afnarius and Ridho Darman. All authors have read and agreed to the published version of the manuscript.

Funding: This research was funded by the Andalas University of BOPTN funds, under the Letter of Agreement for the Implementation of the Research Cluster Research Grant of GB No. 53/UN.16.17/PP.RGB/LPPM/2018.

Conflicts of Interest: The authors declare no conflicts of interest.

\section{References}

1. Soleman, M.; Noer, M. Nawacita: Superior Strategy of Jokowi in October 2014-20 October 2015. Politik 2017, 13, 1961-1975. 
2. Yarni, M. Menuju Desa Yang Maju, Kuat, Mandiri, Dan Demokratis Melalui Undang-Undang No. 6 Tahun 2014 Tentang Desa. Inovatif 2014, VII, 17-27.

3. Ash-Shidiqqi, E.A.; Wibisono, H. Corruption and Village: Accountability of Village Fund Management on Preventing Corruption (Problems and Challenges). JILS 2018, 3, 195-212. [CrossRef]

4. Herdiana, D. Developing the Smart Village Concept for Indonesian Villages. IPTEK-KOM 2019, 21, 1-16. [CrossRef]

5. Skakelja, N.; McGlynn, D. Smart Villages Revitalising Rural Services. EU Rural Rev. $2018,26$. Available online: https:/enrd.ec.europa.eu/publications/eu-rural-review-26-smart-villages-revitalisingrural-services_en (accessed on 31 March 2020).

6. Viswanadham, N. Smart Villages and Smart Cities. Available online: https://www.csa.iisc.ac.in/ \{\}nv/ 66SmartVillagesandSmartCitiesGAI14022011.pdf (accessed on 7 July 2019).

7. Syaodih, E. Smart Village Development. In Proceedings of the 9th International Conference of Rural Research and Planning Group, Den Pasar, Indonesia, 6-8 July 2018.

8. Tanchareon, S. Energy for Off-Grid Villages in Thailand. In Proceedings of the Smart Villages in Southeast Asia Workshop, Kuching, Malaysia, 27-29 January 2015.

9. Bala, P. e-Bario Project. In Proceedings of the Smart Villages in Southeast Asia Workshop, Kuching, Malaysia, 27-29 January 2015.

10. Yeo, A. Long Lamai Case Study. In Proceedings of the Smart Villages in Southeast Asia Workshop, Kuching, Malaysia, 27-29 January 2015.

11. Ranade, P.; Londhe, S.; Mishra, A. Smart Villages through Information Technology-Need of Emerging India. IIJIT 2015, 3, 1-6.

12. Fajrillah, F.; Mohamad, Z.; Novarika, W. Smart City VS Smart Village. J. Mantik Penusa 2018, 22, 1-6.

13. Zavratnik, V.; Kos, A.; Duh, E.S. Smart Villages: Comprehensive Review of Initiatives and Practices. Sustainability 2018, 10, 2559. [CrossRef]

14. Sarangi, S.S.; Singha, G. A Survey on Impact of AI and Social Media for Rural Development. JCSE 2019, 7, 64-68.

15. Alamanda, D.T.; Anggadwita, G.; Raynaldi, M.; Novani, S.; Kijima, K. Designing Strategies using IFE, EFE, IE, and QSPM analysis: Digital Village Case. AJTM 2019, 12, 48-57. [CrossRef]

16. Afnarius, S.; Putra, A.T.; Tamara, A.; Dinata, U.G.S.; Ichwana, D.; Akbar, F. Web GIS development for Minangkabau Customary village: A case study of Padang Lua Village, West Sumatra, Indonesia. IJG 2017, $13,1-8$.

17. Sushma, S. A Comparative Study of Smart City vs. Smart Villages Startup, Opportunities and Challenges. Asian J. Manag. 2017, 8, 1315-1321. [CrossRef]

18. Kaushik, S.; Kandpal, K.C.; Pandey, A. Application of GIS in Panchayati Raj System in India: A Case Study of Naugaon Village, Uttarakhand, India (An Initiative of G-governance). IJARSG 2017, 6, 2367-2376. [CrossRef]

19. Sukla, P.Y. The Indian smart village: Foundation for growing India. IJAR 2016, 2, 72-74.

20. Bhondve, A.; Wakode, K.; Surve, A.; Patil, A.; Ambhure, R.; Mhetre, S.; Mane, P. Data Analysis of Village Sangawade (An Approach to Town Planning). IJRASET 2018, 6, 265-269. [CrossRef]

21. Tongco, A.F. Developing a GIS for Rural Villages in the Philippines. IAMURE Int. J. Multidisc. Res. 2011, 1, 15-35. [CrossRef]

22. Darman, R.; Afnarius, S. Developing WebGIS for Buildings in Koto Gadang, Agam Regency, West Sumatra Province. In Proceedings of the International Conference on ASEAN 2019, Padang, Indonesia, 5-6 September 2019.

23. Prakash, R.S.; Poul, P.V.; Nilesh, K.D. Application of Geoinformatics for Smart Village Creation. IJCIR 2017, 13, 1073-1081.

24. Guo, Z.; Shao, X.; Xu, Y.; Miyazaki, H.; Ohira, W.; Shibasaki, R. Identification of Village Building via Google Earth Images and Supervised Machine Learning Methods. Remote Sens. 2016, 8, 271. [CrossRef]

25. Arida, I.N.S.; Wiguna, P.P.K.; Narka, I.W.; Febrianti, N.K.O. Development Planning of Tourist Village Using Participatory Mapping (Case study: Mambal Village, Badung Regency, Indonesia). IOP Conf. Ser. Earth Environ. Sci. 2017, 98, 012044. [CrossRef]

26. Prasetyo, N.Y.; Nugraha, A.L. Kajian Terapan Teknologi UAV dan SIG dalam Pembuatan Peta Desa Skala 1:1000 untuk Wilayah RW-04 Kelurahan Tembalang Tahun 2017. J. Geodesi Undip 2019, 8, 1-9. 
27. Hartono, D.; Darmawan, S. Pemanfaatan Unmanned Aerial Vehicle (UAV) Jenis Quadcopter untuk Percepatan Pemetaan Bidang Tanah (Studi Kasus: Desa Solokan Jeruk Kabupaten Bandung). Reka Geomatika 2018, 2018, 30-40. [CrossRef]

28. Azizah, A.N.; Purwanto, T.H.; Zuharnen, Z. Village Mapping Using Unmanned Aerial Vehicle In Kepek's Village, Wonosari, Gunungkidul. In Proceedings of the Seminar Nasional Geomatika 2017, Cibinong, Indonesia, 14 November 2017. [CrossRef]

29. Marizka, M.; Afnarius, S. Development of Web and Mobile GIS Application of Disaster in Padang to support Tourism of West Sumatra Province. In Proceedings of the International Conference on ASEAN 2019, Padang, Indonesia, 5-6 September 2019.

30. Afnarius, S.; Yuliani, F.; Akbar, F. Developing Mobile GIS Application for Religious Tourism and Its Proponent in Bukittinggi City. In Proceedings of the TDC-International Conference 2019, Bukittinggi, Indonesia, 1-2 October 2019.

31. Afnarius, S.; Akbar, F.; Yuliani, F. Developing Web-Based and Mobile-Based GIS for Places of Worship Information to Support Halal Tourism: A Case Study in Bukittinggi, Indonesia. ISPRS Int. J. Geo-Inf. 2020, 9, 52. [CrossRef]

32. Sumiarti, E.; Suryani, Y. Gambaran Industri Kecil dan Menengah (IKM) Kerajinan Perak Koto Gadang Sebagai Salah Satu Kerajinan Unggulan Sumatera Barat. J. Poli Bisnis 2015, 7, 76-87.

33. Rencana Tata Ruang Wilayah Kabupaten Agam 2010-2030. Available online: https://vdocuments.mx/ download/rencana-tata-ruang-wilayah-kabupaten-agam-2010-kabupaten-agam- (accessed on 7 July 2019).

34. Fakhrina, I. Merantau dan Pulang Basamo; Fisipol Unila: Bandar Lampung, Indonesia, 2017; pp. $26-28$.

35. Nata, L. Jalan Sunyi di Nagari Orang-Orang Hebat. Available online: http://wartaandalas.com/berita-jalansunyi-di-nagari-orangorang-hebat.html (accessed on 19 October 2018).

36. Rio, J. Tingkat Kepuasan Wisatawan Terhadap Pelayanan Rumah Makan Tradisional Itiak Lado Hijau Sianok Kuliner; Faterna Unand: Padang, Indonesia, 2017; pp. 2-3.

37. Phantom 4. Available online: https://www.dji.com/id/phantom-4/info (accessed on 7 July 2019).

38. Vaisman, A.; Zimányi, E. Mobility DataWarehouses. ISPRS Int. J. Geo-Inf. 2019, 8, 170. [CrossRef]

39. Lizardo, L.E.O.; Davis, C.A., Jr. A PostGIS extension to support advanced spatial data types and integrity constraints. In Proceedings of the SIGSPATIAL'17, Los Angeles, CA, USA, 7-10 November 2017. [CrossRef]

40. Singh, S.P.; Singh, P. Modeling A Geo-Spatial Database for Managing Travelers' Demand. IJDMS 2014, 6, 39-47. [CrossRef]

41. Bartoszewski, D.; Piorkowski, A.; Lupa, M. The Comparison of Processing Efficiency of Spatial Data for PostGIS and MongoDB Databases. In Proceedings of the Beyond Databases, Architectures and Structures 2019: Paving the Road to Smart Data Processing and Analysis, Ustroń, Poland, 28-31 May 2019; pp. 291-302. [CrossRef]

42. Shukla, D.; Shivnani, C.; Shah, D. Comparing Oracle Spatial and Postgres PostGIS. IJCSC 2016, 7, 95-100. [CrossRef]

43. Makris, A.; Tserpes, K.; Spiliopoulos, G.; Anagnostopoulos, D. Performance Evaluation of MongoDB and PostgreSQL for spatio-temporal data. In Proceedings of the EDBT/ICDT 2019 Joint Conference on CEUR-WS.org, Lisbon, Portugal, 26 March 2019.

(C) 2020 by the authors. Licensee MDPI, Basel, Switzerland. This article is an open access article distributed under the terms and conditions of the Creative Commons Attribution (CC BY) license (http://creativecommons.org/licenses/by/4.0/). 